Vibe, Y., Friedrich, A.M., Bunge, H.-P., and Clark, S.R., Correlations of oceanic spreading rates and hiatus surface area in the North Atlantic realm: Lithosphere,

https://doi.org/10.1130/L736.1.

GSA Data Repository Item 2018310

\title{
Data Repository Information \\ CORRELATIONS OF OCEANIC SPREADING RATES AND HIATUS SURFACE AREA IN THE NORTH ATLANTIC REALM
}

\author{
Yulia Vibe $^{1,2}$, A.M. Friedrich ${ }^{1}$, H.- P. Bunge ${ }^{1}$, and S. R. Clark ${ }^{2}$ \\ ${ }^{1}$ Department of Geo and Environmental Sciences, Ludwig-Maximilians-Universität München, \\ Theresienstrasse 41 und Luisenstrasse 37, 80333 München, Germany \\ ${ }^{2}$ Kalkulo AS, Simula Research Laboratory, P.O.Box 134, 1325 Lysaker, Norway
}

\section{TABLE OF CONTENTS}

1. Appendix $1-$ Calculation of hiatus area in Figure 7

2. TABLE DR1. Width and duration of magnetic lineations for the NW-Atlantic sea floor

3. TABLE DR2. Overview of geological data related to erosion and uplift in Europe.

4. References for Table DR2

5. TABLE DR3. Rotations used to calculate the velocity of Europe relative to North America

\section{Appendix 1 - Calculation of hiatus area in Figure 7}

The area of hiatus the northern part $\left(30^{\circ} \mathrm{W}\right.$ to $40^{\circ} \mathrm{E}$ and $80^{\circ} \mathrm{N}$ to $\left.45^{\circ} \mathrm{N}\right)$ of hiatus maps using the grdvolume function of GMT tool, considering all hiatus values above 0 .

$\begin{array}{lccccc}\text { Age }(M a) & 66 & 55 & 34 & 23 & 5 \\ \text { Area }\left(10^{7} * k^{2}\right) & 0.22 & 0.3 & 0.08 & 0.45 & 0.26\end{array}$


TABLE DR1. Width and duration of magnetic lineations for the western North Atlantic sea floor

\begin{tabular}{|c|c|c|c|c|}
\hline $\begin{array}{l}\text { Lineation } \\
\text { name in this } \\
\text { paper }^{2}\end{array}$ & $\begin{array}{l}\text { Width } \\
(\mathrm{km})\end{array}$ & $\begin{array}{c}\text { Duration of } \\
\text { isochron intervals } \\
\text { (m.y.) }\end{array}$ & Isochron Names $^{1}$ & $\begin{array}{c}\text { Isochron Ages }^{1} \\
\text { (Ma) }\end{array}$ \\
\hline $\mathrm{A}$ & 7 & 0.8 & $\mathrm{C} 2$ & $1.8-2.6$ \\
\hline B & 12 & 1 & $\mathrm{C} 2 \mathrm{An}$ & $2.6-3.6$ \\
\hline $\mathrm{C}$ & 5 & 0.6 & $\mathrm{C} 2 \mathrm{Ar}$ & $3.6-4.2$ \\
\hline $\mathrm{D}$ & 15 & 1 & C $3 n .1 n(y)-C 3 n .4 n(o)$ & $4.2-5.2$ \\
\hline $\mathrm{E}$ & 7 & 0.8 & C $3 r .4 r$ & $5.2-6.0$ \\
\hline $\mathrm{F}$ & 8 & 0.6 & $\mathrm{C} 3 \mathrm{~A} 1 \mathrm{n}-\mathrm{C} 3 \mathrm{~A} 2 \mathrm{n}$ & $6.0-6.7$ \\
\hline G & 10 & 0.8 & $\mathrm{C} 3 \mathrm{~A} 2 \mathrm{n}(\mathrm{o})-\mathrm{C} 4 \mathrm{n} 1 \mathrm{n}(\mathrm{y})$ & $6.7-7.5$ \\
\hline $\mathrm{H}$ & 9 & 0.6 & $\mathrm{C} 4 \mathrm{n} 1 \mathrm{n}(\mathrm{y})-\mathrm{C} 4 \mathrm{n} 2 \mathrm{n}(\mathrm{o})$ & $7.5-8.1$ \\
\hline I & 13 & 1 & $\mathrm{C} 4 \mathrm{n} 2 \mathrm{n}(\mathrm{o})-\mathrm{C} 4 \mathrm{An}(\mathrm{o})$ & $8.1-9.1$ \\
\hline $\mathrm{J}$ & 7 & 0.8 & $\mathrm{C} 4 \mathrm{An}(\mathrm{o})-\mathrm{C} 5 \mathrm{n} \cdot 1 \mathrm{n}(\mathrm{y})$ & $9.1-9.78$ \\
\hline K & 20 & 1.2 & $\mathrm{C} 5 \mathrm{n} .1 \mathrm{n}(\mathrm{y})-\mathrm{C} 5 \mathrm{n} .2 \mathrm{n}(\mathrm{o})$ & $9.78-11.0$ \\
\hline $\mathrm{L}$ & 18 & 1.4 & $\mathrm{C} 5 \mathrm{n} \cdot 2 \mathrm{n}(\mathrm{o})-\mathrm{C} 5 \mathrm{An} \cdot 2 \mathrm{n}(\mathrm{o})$ & $11.0-12.4$ \\
\hline M & 20 & 1.2 & $\mathrm{C} 5 \mathrm{An} .2 \mathrm{n}(\mathrm{o})-\mathrm{C} 5 \mathrm{ACn}(\mathrm{y})$ & $12.5-13.7$ \\
\hline $\mathrm{N}$ & 40 & 3.5 & $\mathrm{C} 5 \mathrm{ACn}(\mathrm{y})-\mathrm{C} 5 \mathrm{Dn}(\mathrm{y})$ & $13.7-17.2$ \\
\hline $\mathrm{O}$ & 34 & 2.6 & C5Dn(y) - C6n(o) & $17.2-19.7$ \\
\hline $\mathrm{P}$ & 130 & 13.6 & C6n(o) - C13n(y) & $19.7-33.2$ \\
\hline Q & 75 & 6.4 & $\mathrm{C} 13 \mathrm{n}(\mathrm{y})-\mathrm{C} 18 \mathrm{n} \cdot 1 \mathrm{n}(\mathrm{o})$ & $33.2-39.8$ \\
\hline $\mathrm{R}$ & 40 & 3.6 & $\mathrm{C} 18 \mathrm{n} .1 \mathrm{n}(\mathrm{o})-\mathrm{C} 20 \mathrm{n}(\mathrm{o})$ & $39.8-43.5$ \\
\hline $\mathrm{S}$ & 51 & 4.3 & $\mathrm{C} 20 \mathrm{n}(\mathrm{o})-\mathrm{C} 2 \ln (\mathrm{o})$ & $43.5-47.8$ \\
\hline $\mathrm{T}$ & 28 & 2 & $\mathrm{C} 21 \mathrm{n}(\mathrm{o})-\mathrm{C} 22 \mathrm{n}(\mathrm{o})$ & $47.8-49.7$ \\
\hline $\mathrm{U}$ & 41 & 2.2 & $C 22 n(o)-C 23 n .2 n(o)$ & $49.7-51.9$ \\
\hline $\mathrm{V}$ & 63 & 2 & $C 23 n .2 n(o)-C 24 n .3 n(o)$ & $51.9-53.9$ \\
\hline $\mathrm{W}$ & 78 & 3.8 & $\mathrm{C} 24 \mathrm{n} .3 \mathrm{n}(\mathrm{o})-\mathrm{C} 25 \mathrm{n}(\mathrm{o})$ & $53.9-57.7$ \\
\hline$X$ & 43 & 1.5 & $\mathrm{C} 25 \mathrm{n}(\mathrm{o})-\mathrm{C} 26 \mathrm{n}(\mathrm{o})$ & $57.7-59.2$ \\
\hline Y & 86 & 3.3 & $\mathrm{C} 26 \mathrm{n}(\mathrm{o})-\mathrm{C} 27 \mathrm{n}(\mathrm{o})$ & $59.2-62.5$ \\
\hline $\mathrm{Z}$ & 38 & 6.8 & $\mathrm{C} 27 \mathrm{n}(\mathrm{o})-\mathrm{C} 3 \ln (\mathrm{o})$ & $62.5-69.3$ \\
\hline
\end{tabular}


TABLE DR2. Overview of geological data related to erosion and uplift in Europe.

\begin{tabular}{|c|c|c|c|}
\hline Time & Location & Source & Interpretation \\
\hline \multirow[t]{3}{*}{$\begin{array}{l}\text { Base } \\
\text { Paleocene }\end{array}$} & British Isles & $\begin{array}{l}\text { Thermochronology (Green et al., 2002) } \\
\text { Backstripping analysis (Mackay et al., } \\
\text { 2005) }\end{array}$ & Transient uplift of $180-425 \mathrm{~m}$ occurred during Paleocene times. \\
\hline & North Sea & $\begin{array}{l}\text { Stratigraphy (Anell et al., 2012; Evans, } \\
\text { 2003) }\end{array}$ & $\begin{array}{l}\text { The studies report thick deposits of presumably eroded material } \\
\text { adjacent to the northern North Sea, the Scottish Highlands and } \\
\text { the East Shetland Platform with thinner deposits next to southern } \\
\text { Norway }\end{array}$ \\
\hline & Scandes & $\begin{array}{l}\text { Landform study (Lidmar-Bergström and } \\
\text { Näslund, 2002) } \\
\text { Thermochronology (Hendriks et al., } \\
\text { 2007; Hendriks and Andriessen, 2002) }\end{array}$ & Uplift of the Scandes during late Cretaceous-Paleocene time. \\
\hline \multirow[t]{4}{*}{$\begin{array}{l}\text { Base } \\
\text { Eocene }\end{array}$} & $\begin{array}{l}\text { Rhine } \\
\text { Graben }\end{array}$ & Geologicasl study (Ziegler, 1992) & $\begin{array}{l}\text { Magmatic dyke intrusions are documented in the Cretaceous- } \\
\text { Late Paleocene strata. }\end{array}$ \\
\hline & Pyrenees & Stratigraphy (Burbank et al., 1992) & $\begin{array}{l}\text { The main stages of shortening in the Pyrenees took place from } \\
\text { Paleocene to Early Oligocene }\end{array}$ \\
\hline & Porcupine & $\begin{array}{l}\text { Subsidence modelling } \\
\text { (Jones et al., 2001) }\end{array}$ & Transient uplift of 300-600 $\mathrm{m}$ at Paleocene-Eocene boundary. \\
\hline & $\begin{array}{l}\text { Faroe- } \\
\text { Shetland }\end{array}$ & $\begin{array}{l}\text { Stratigraphy (Champion et al., 2008; } \\
\text { Lundin and Doré, 2002) }\end{array}$ & Transient uplift of about $550 \mathrm{~m}$ in $3 \mathrm{m.y}$.; Dome formation. \\
\hline $\begin{array}{l}\text { Base } \\
\text { Oligocene }\end{array}$ & $\begin{array}{l}\text { Upper } \\
\text { Rhine }\end{array}$ & $\begin{array}{l}\text { Paleotectonic maps (Dèzes et al., } \\
\text { 2004). }\end{array}$ & $\begin{array}{l}\text { Eocene activation of the fault systems with main rifting stage in } \\
\text { the Oligocene. }\end{array}$ \\
\hline
\end{tabular}




\begin{tabular}{|c|c|c|c|}
\hline & $\begin{array}{l}\text { Graben, } \\
\text { Bohemian } \\
\text { Massif }\end{array}$ & & \\
\hline \multirow[t]{4}{*}{$\begin{array}{l}\text { Base } \\
\text { Miocene }\end{array}$} & Porcupine & $\begin{array}{l}\text { Stratigraphy } \\
\text { (Stoker et al., 2005; Stoker and Shanon, } \\
2005 \text { ) }\end{array}$ & $\begin{array}{l}\text { The Base Miocene and Mid-Miocene significant unconformities } \\
\text { recognized in the Rockall Porcupine and Farroe-Shetland due to } \\
\text { tectonism Formation of domes. }\end{array}$ \\
\hline & $\begin{array}{l}\text { Paris Basin } \\
\& \text { Western } \\
\text { Approaches }\end{array}$ & Paleotectonic maps (Dèzes et al., 2004) & Basin inversions. \\
\hline & $\begin{array}{l}\text { Mediterran- } \\
\quad \text { ean }\end{array}$ & $\begin{array}{l}\text { Geodynamic models based on } \\
\text { sedimentary and structural data } \\
\text { (Séranne, 1999) }\end{array}$ & $\begin{array}{l}\text { 28-20 Ma rifting in the Western Mediterranean and Late } \\
\text { Ruppelian unconformity in the Gulf of Lion (Southern France). }\end{array}$ \\
\hline & $\begin{array}{l}\text { West } \\
\text { Siberian } \\
\text { Basin }\end{array}$ & $\begin{array}{l}\text { Subsidence modelling (Vibe et al., } \\
\text { 2018) }\end{array}$ & No subsidence since the Middle Oligocene. \\
\hline \multirow[t]{3}{*}{$\begin{array}{l}\text { Base } \\
\text { Pliocene }\end{array}$} & British Isles & $\begin{array}{l}\text { Thermochronology (Holford et al., } \\
\text { 2005) }\end{array}$ & $\begin{array}{l}\sim 1.5 \mathrm{~km} \text { Neogene ( } 20-0 \mathrm{Ma} \text { ) uplift inferred by the AFT and } \\
\text { compaction studies in the Mochras (NW Wales) borehole. }\end{array}$ \\
\hline & North Sea & $\begin{array}{l}\text { Stratigraphy (Anell et al., 2012; Evans, } \\
\text { 2003) }\end{array}$ & Mid- to Late Miocene hiatus of 5-12 m.y. \\
\hline & Scandes & $\begin{array}{l}\text { Isostatic modelling and study of } \\
\text { landforms (Riis, 1996; Riis and } \\
\text { Fjeldskaar, 1992; Stuevold and } \\
\text { Eldholm, 1996; Lidmar-Bergström et } \\
\text { al., 2013). Thermochronology }\end{array}$ & $\begin{array}{l}\sim 1000 \mathrm{~m} \text { of Neogene uplift in Southern Scandinavia and } \\
\text { acceleration denudation in the northern Scandes. }\end{array}$ \\
\hline
\end{tabular}


(Hendriks and Andriessen, 2002; Japsen

$$
\text { et al.,2014) }
$$

Western Stratigraphy (Eidvin et al., 2014)

Barents Sea Thermochronology (Zattin et al., 2016)

Western Thermochronology (Japsen et al., 2005)
Documented hiatus in the Vestbakken Volcanic Province from the Lower Miocene to Late Pliocene. Thermochronology data indicates an exhumation event of $\sim 1000 \mathrm{~m}$ magnitude.

Documents an uplift around 11-10 Ma and 7-2 Ma .

\section{References for Table DR2:}

Anell, I., Thybo, H., Rasmussen, E., 2012, A synthesis of Cenozoic sedimentation in the North Sea: Basin Research $24,154-179$.

Burbank, D.W., Puigdefabregas, C.A.I., Munoz, J.A., 1992, The chronology of the Eocene tectonic and stratigraphic development of the eastern Pyrenean foreland basin, northeast Spain: Geological Society of America Bulletin 104, 1101-1120.

Champion, M.E., White, N.J., Jones, S.M., Lovell, J.P.B., 2008, Quantifying transient mantle convective uplift: An example from the FaroeShetland basin: Tectonics 27.

Dèzes, P., Schmid, S.M., Ziegler, P.A., 2004, Evolution of the European Cenozoic Rift System: interaction of the Alpine and Pyrenean orogens with their foreland lithosphere: Tectonophysics 389, 1-33.

Eidvin, T., Riis, F., Rasmussen, E.S., 2014, Oligocene to Lower Pliocene deposits of the Norwegian continental shelf, Norwegian Sea, Svalbard, Denmark and their relation to the uplift of Fennoscandia: A synthesis: Marine and Petroleum Geology 56, $184-221$.

Evans, D., 2003, The Millennium Atlas: Petroleum Geology of the Central and Northern North Sea: London, Geological Society of London, the Geological Survey of Denmark and Greenland and the Norwegian Petroleum Society.

Green, P.F., Duddy, I.R., Hegarty, K.A., 2002, Quantifying exhumation from apatite fission-track analysis and vitrinite reflectance data: precision, accuracy and latest results from the Atlantic margin of NW Europe: Geological Society of London, Special Publications $196,331-354$.

Hendriks, B., Andriessen, P., Huigen, Y., Leighton, C., Redfield, T., Murrell, G., Gallagher, K., Nielsen, S.B., 2007, A fission track data compilation for Fennoscandia: Norsk Geologisk Tidsskrift 87, 143.

Hendriks, B.W., Andriessen, P.A., 2002, Pattern and timing of the post-Caledonian denudation of northern Scandinavia constrained by apatite fission-track thermochronology: Geological Society of London, Specical Publications 196, 117-137. 
Holford, S.P., Green, P.F., Turner, J.P., 2005, Palaeothermal and compaction studies in the Mochras borehole (NW Wales) reveal early Cretaceous and Neogene exhumation and argue against regional Palaeogene uplift in the southern Irish Sea: Journal of the Geological Society 162, 829-840.

Japsen, P., Green, P.F., Lidmar-Bergström, K., Bonow, J.M., Erlström, M., 2014, Burial and exhumation history of southern Sweden estimated from apatite fission-track data, stratigraphic landform analysis and the geological record: Geophysical Research Abstracts Vol. 16, Vienna, EGU General Assembly 2014, p. 6814.

Japsen, P., Green, P.F., Chalmers, J.A., 2005, Separation of Palaeogene and Neogene uplift on Nuussuaq, West Greenland: Journal of the Geological Society 162, 299-314.

Jones, S.M., White, N., Lovell, B., 2001, Cenozoic and Cretaceous transient uplift in the Porcupine Basin and its relationship to a mantle plume: Geological Society of London, Special Publications 188, 345-360.

Lidmar-Bergström, K., Bonow, J.M., Japsen, P., 2013, Stratigraphic Landscape Analysis and geomorphological paradigms: Scandinavia as an example of Phanerozoic uplift and subsidence: Global and Planetary Change 100, 153-171.

Lidmar-Bergström, K., Näslund, J.O., 2002, Landforms and uplift in Scandinavia: Geological Society of London, Special Publications 196, 103-116.

Lundin, E., Doré, A.G., 2002, Mid-Cenozoic post-breakup deformation in the "passive" margins bordering the Norwegian-Greenland Sea: Marine and Petroleum Geology 19, 79-93.

Mackay, L.M., Turner, J., Jones, S.M., White, N.J., 2005, Cenozoic vertical motions in the Moray Firth Basin associated with initiation of the Iceland Plume: Tectonics 24.

Riis, F., 1996, Quantification of Cenozoic vertical movements of Scandinavia by correlation of morphological surfaces with offshore data: Global and Planetary Change 12, $331-357$.

Riis, F., Fjeldskaar, W., 1992, On the magnitude of the Late Tertiary and Quaternary erosion and its significance for the uplift of Scandinavia and the Barents Sea, in: Structural and Tectonic Modelling and Its Application to Petroleum Geology: Amsterdam, Elsevier, pp. 163-185.

Séranne, M., 1999, The Gulf of Lion continental margin (NW Mediterranean) revisited by IBS: an overview: Geological Society of London, Special Publications 156, 1536.

Stoker, M.S., Hoult, R.J., Nielsen, T., Hjelstuen, B.O., Laberg, J.S., Shannon, P.M., Praeg, D., Mathiesen, A., Van Weering, T.C.E., McDonnell, A., 2005, Sedimentary and oceanographic responses to early Neogene compression on the NW European margin: Marine and Petroleum Geology 22, 1031-1044.

Stoker, M.S., Shannon, P.M., 2005, Neogene evolution of the NW European Atlantic margin: Results from the STRATAGEM project: Marine and Petroleum Geology 22, 965-968.

Stuevold, L.M., Eldholm, O., 1996, Cenozoic uplift of Fennoscandia inferred from a study of the mid-Norwegian margin: Global and Planetary Change 12, 359-386.

Vibe, Y., Bunge, H.-P., Clark, S.R., 2018, Anomalous subsidence history of the West Siberian Basin as an indicator for episodes of mantle induced dynamic topography: Gondwana Research 53, https://doi.org/10.1016/j.gr.2017.03.011 
Zattin, M., Andreucci, B., de Toffoli, B., Grigo, D., Tsikalas, F., 2016, Thermochronological constraints to late Cenozoic exhumation of the Barents Sea Shelf: Marine and Petroleum Geology 73, 97-104.

Ziegler, P.A., 1992, European Cenozoic rift system: Tectonophysics 208, 91-111.

TABLE DR3. Rotations used to calculate the velocity of Europe relative to North America

\begin{tabular}{lcccl}
\hline \hline Time (Ma) & $\begin{array}{c}\text { Euler pole } \\
\text { lat. }\end{array}$ & $\begin{array}{c}\text { Euler pole } \\
\text { lon. }\end{array}$ & $\alpha$ & \\
0.78 & 62.7 & 138.1 & -0.157 & Merkouriev and DeMets (2014), \\
1.78 & 62.8 & 137.93 & -0.37 & Timescale GTS12, noise reduction by \\
2.58 & 62.94 & 137.79 & -0.54 & Redback \\
3.6 & 63.16 & 137.58 & -0.76 & \\
4.19 & 63.31 & 137.44 & -0.89 & \\
5.24 & 63.64 & 137.17 & -1.11 & \\
6.03 & 63.93 & 136.94 & -1.29 & \\
6.73 & 64.2 & 136.75 & -1.44 & \\
7.53 & 64.52 & 136.53 & -1.64 & \\
8.11 & 64.75 & 136.37 & -1.8 & \\
9.11 & 65.18 & 136.06 & -2.07 & \\
9.79 & 65.5 & 135.84 & -2.26 & \\
11.06 & 66.03 & 135.47 & -2.61 & \\
12.47 & 66.49 & 135.16 & -2.99 & \\
13.74 & 66.86 & 134.87 & -3.33 & \\
14.61 & 67.23 & 134.61 & -3.58 & \\
15.97 & 67.82 & 134.16 & -3.99 & \\
17.23 & 68.35 & 133.73 & -4.36 & \\
18.06 & 68.69 & 133.44 & -4.6 & \\
18.75 & 68.98 & 133.2 & -4.8 & \\
19.72 & 69.39 & 132.89 & -5.08 & \\
20.1 & 68.91 & 132.51 & -5.09 & Gaina (2002), Timescale GTS12 \\
33.16 & 68.22 & 131.53 & -7.65 & \\
39.63 & 67.72 & 133.91 & -9.25 & \\
47.35 & 65.38 & 138.44 & -10.96 & \\
49.34 & 64.52 & 138.18 & -11.5 & \\
53.98 & 63.07 & 144.26 & -12.82 & \\
57.1 & 56.17 & 145.06 & -13.24 & \\
69.2 & 54.45 & 147.06 & -15.86 & \\
79.9 & 63.4 & 147.75 & -18.48 & \\
& & & & \\
& 6 & 63 & &
\end{tabular}

